\title{
ETIKA KOMUNIKASI ISLAMI
}

\author{
Joko Susanto \\ Program Studi Komunikasi dan Penyiaran Islam STAI As-Sunnah Deli Serdang \\ Jl. Medan-Tg. Morawa, Km. 13 Gang Darmo, Desa Bangun Sari, Kab. Deli Serdang \\ Joko_susanto@ymail.com
}

\begin{abstract}
Abstrak: Salah satu potensi manusia yang telah ada semenjak ia dilahirkan dan merupakan anugerah dari Allah SWT adalah berkomunikasi. Komunikasi bagi manusia merupakan kebutuhan paling mendasar dalam hidupnya, hampir seluruh aktivitas manusia dalam kehidupan pribadi dan sosialnya tidak bisa terpisahkan dari komunikasi, sehingga manusia tidak dapat hidup dan berkembang tanpa berkomunikasi. Komunikasi adalah sebuah proses menyampaikan pesan dari komunikator kepada komunikan untuk sebuah tujuan tertentu, selain itu komunikasi juga dapat dipahami sebagai sebuah proses bagaimana kita memahami dan dipahami orang lain. Kegiatan komunikasi harus dilakukan berdasarkan nilai-nilai etika yang dianut dalam sebuah masyarakat, hal ini dimaksudkan agar komunikasi yang dilakukan menyenangkan, memberi kebaikan dan memberi manfaat bagi pelaku komunikasi. Islam sebagai agama rahmat, ajarannya diyakini memberi kebaikan dalam kehidupan umat manusia. Islam juga menempatkan komunikasi sebagai sesuatu yang penting dan bernilai ibadah apabila komunikasi itu dilakukan berdasarkan nilai-nilai yang terdapat dalam alquran dan sunnah Nabi SAW, keduanya merupakan pedoman yang berisi tuntunan hidup bagi setiap muslim yang harus dijunjung tinggi dan menjadi ukuran-ukuran dalam berkomunikasi. Etika komunikasi islami dimaksudkan sebagai sebuah nilai-nilai yang baik yang pantas dan memiliki manfaat ketika melakukan proses komunikasi, apakah komunikasi itu berupa komunikasi interpersonal, komunikasi kelompok, komunikasi organisasi atau komunikasi massa kesemua bentuk komunikasi yang akan dilakukan tersebut harus didasarkan pada nilainilai alquran dan sunnah Nabi SAW. Nilai-nilai etika komunikasi islami yang tertuang dalam alquran dan sunnah Nabi SAW meliputi nilai-nilai kejujuran (kebenaran). Nilai kejujuran ini meliputi nilai-nilai keadilan, kewajaran dan kepatutan. Etika komunikasi yang lain adalah nilai Falyakul Khairan au liyasmut (Katakan yang baik atau diam), selanjutnya yang terakhir adalah nilai tabayyun. Ketiga nilai etika komunikasi islami ini merupakan pendidikan berkomunikasi bagi setiap muslim dalam menciptakan komunikasi yang baik menurut ajaran Islam.
\end{abstract}

Kata Kunci : Etika Komunikasi Islami: Kejujuran, Falyakul Khairan au liyasmut, Tabayyun.

\section{Pendahuluan}

Sebahagian kita mungkin menggangap komunikasi adalah sesuatu yang biasa dan sederhana, sehingga seringkali kita lalai untuk memperhatikan bagaimana seharusnya berkomunikasi yang baik terhadap sesama manusia terutama terhadap keluarga, teman dan orang lain di sekitar kita. Tanpa disadari 
bahwa komunikasi yang kita lakukan telah membawa banyak manfaat, kebaikan dan manfaat dalam kehidupan kita, disisi yang lain komunikasi juga telah banyak menimbulkan mudarat, konflik, kerugian dan bahkan bencana dalam kehidupan manusia. Hal tersebut terjadi karena manusia lupa dalam menempatkan dan menjunjung tinggi etika dalam berkomunikasi.

disadari atau tidak bahwa sebahagian besar hidup manusia diisi oleh kegiatan berkomunikasi. Sejak bangun dari tidur hingga tidur kembali, manusia telah melakukan komunikasi dengan dirinya sendiri (komunikasi intrapersonal), berkomunikasi dengan orang lain secara langsung (komunikasi interpersonal), melakukan hubungan dalam kelompok sosialnya (komunikasi kelompok), menjadi bagian dari sebuah organisasi (komunikasi organisasi), atau bahkan melakukan komunikasi dengan masyarakat secara luas (komunikasi massa). Hal itu menunjukkan bahwa manusia telah berkomunikasi dengan begitu banyak orang dalam lingkungan sosialnya yang berbeda latar belakang secara geografis, demografis, psikologis dan politis. Sehingga manusia tidak dapat tidak berkomunikasi (we cannot not communicate).

Manusia sebagai makhluk pribadi dan mahluk sosial menduduki posisi yang sangat penting dan strategis. Sebab, hanya manusialah satu-satunya makhluk Allah SWT yang diberikan amanah sebagai khalifah dimuka bumi dan dikarunia kemampuan berkomunikasi. Alquran menyebutkannya dengan kata al bayan ${ }^{1}$. Dengan kemampuan itulah memungkinkan manusia membangun hubungan sosialnya. Kemampuan berkomunikasi yang dimiliki manusia adalah sebuah keadaan dimana komunikasi yang dilakukan dapat membentuk saling pengertian dan menumbuhkan persahabatan, memelihara kasih sayang, menyebarkan pengetahuan, dan melestarikan peradaban dan sebagainya. Disisi lain, kemampuan dalam berkomunikasi ini juga telah menciptakan perpecahan, permusuhan, menanamkan kebencian, merintangi kemajuan, dan menghambat pemikiran, konflik yang berkepanjangan serta bencana yang besar dimuka bumi, hal tersebut

${ }^{1}$ Saefullah, Kapita Selekta Komunikasi: Pendekatan Agama dan Budaya, (Bandung, Simbiosa Rekatama Media, 2007), h. 67 
merupakan sebuah realitas yang tidak boleh dinafikan dan telah terjadi dalam kehidupan umat manusia.

Jika dilihat secara objektif dan konfrehensif bahwa komunikasi seperti dua sisi mata uang yaitu bahwa disisi yang satu menunjukkan komunikasi merupakan jalan menuju kebaikan bersama, namun di sisi yang lain komunikasi juga turut menyebabkan permasalahan, konflik dan permusuhan yang berkepanjangan di tengah-tengah manusia. Hal itu dapat terjadi manakala komunikasi dilakukan tidak didasarkan pada etika-etika komunikasi. Kenyataan ini sekaligus memberi gambaran betapa komunikasi menjadi sesuatu yang sentral dan signifikan dalam setiap ruang dimensi kehidupan manusia, sehingga komunikasi tidak hanya dipahami sekedar kegiatan bicara-bicara semata melainkan bagaimana pembicaraan yang dilakukan tersebut penuh makna, penuh rasa dan membawa bahagia bagi setiap pelakunya. Hal ini dapat terjadi apabila alquran dan sunnah Nabi Saw dijadikan sebagai landasan etika berkomunikasi.

Dalam perspektif Islam, komunikasi dipandang sebagai upaya untuk membangun hubungan secara vertikal dengan Allah SWT (Hablumminallah) dan juga untuk menjalin komunikasi secara horizontal yaitu hubungan dengan sesama manusia (hablumminanas). Komunikasi dengan Allah SWT tercermin melalui ibadah-ibadah yang telah ditentukan seperti salat, puasa, zakat dan haji, zikir dan sebagainya dengan tujuan untuk mendekatkan diri kepada-Nya dan membentuk karakter taqwa dalam diri hamba. Sedangkan komunikasi dengan sesama manusia terwujud melalui penekanan hubungan sosial yang disebut muamalah, yang tercermin dalam semua aspek kehidupan manusia, seperti sosial, budaya, politik, ekonomi, seni dan sebagainya dengan tujuan untuk mewujudkan kebaikan dan kesejahteraan manusia.

\section{Ruang Lingkup Komunikasi}

Istilah komunikasi atau dalam bahasa Inggris communication berasal dari bahasa latin yaitu communicatio yang biasa dipakai untuk menjelaskan kemampuan manusia memilih label dan simbol tertentu, atau menjelaskan 
hubungan diantara manusia dan hubungan manusia dengan dunia disekeliling mereka. Kata communication sebenarnya berasal dari dua akar kata yaitu com (dalam bahasa latin cum yang berarti dengan atau bersama-sama dengan) dan unio (dalam bahasa latin union yang diartikan sebagai persatuan). Jadi communication menjelaskan to union with or union together with - menjadi satu dengan atau bersama-sama dengan ${ }^{2}$. Komunikasi secara etimologis berasal dari perkataan latin communicatio istilah ini sesungguhnya berasal dari kata communis yang berarti sama sama yang dimaksudkan disini adalah sama makna atau sama arti. Jadi dalam pendekatan etimologi komunikasi terjadi apabila terdapat kesamaan makna mengenai suatu pesan yang disampaikan oleh komunikator dan diterima oleh komunikan ${ }^{3}$.

Selanjutnya, kata komunikasi bagi para ahli memiliki pengertian yang beragam sesuai dengan konteks komunikasi. menurut catatan Dance dan Larson di tahun 1976 mengungkapkan bahwa setidaknya sudah ada 126 definisi komunikasi yang diutarakan para ahli berdasarkan keragaman perspektif yang dimiliki masing-masing. Ahli psikologi melihat komunikasi sebagai proses stimulus untuk menimbulkan respon tertentu, ahli sosiologi melihat komunikasi sebagai proses interaksi, ahli politik melihat komunikasi sebagai perebutan pengaruh dan kekuasaan, dan lain sebagainya. Keragaman definisi yang dibuat para ahli menunjukkan bahwa ilmu komunikasi begitu dinamis dan luas untuk dikaji ${ }^{4}$.

Sesungguhnya komunikasi sebagai sebuah ilmu dan seni sudah mulai berkembang pada zaman Yunani kuno, tokoh yang banyak berjasa salah satunya adalah Aristoteles (358-322 SM). Dalam bukunya Rethoric, Aristoteles mendefinisi komunikasi sebagai berikut : "siapa mengatakan apa kepada siapa". Definisi yang dibuat Aristoteles tersebut begitu sederhana, akan tetapi terus menjadi acuan dalam perkembangan ilmu komunikasi sampai saat ini, hingga ditemukan beragamnya definisi komunikasi oleh para ahli untuk menjelaskan dan

\footnotetext{
${ }^{2}$ Liliweri, Komunikasi : Serba Ada Serba Makna, (Jakarta : Kencana, 2011), h. 31.

${ }^{3}$ Effendy, Ilmu, Teori dan Filsafat Komunikasi, (Bandung: Citra Aditya Bakti, 2003), h.30.

${ }^{4}$ Cangara, Komunikasi Politik; Konsep, Teori dan Strategi, (Jakarta : Raja Grafindo Persada, 2009), h. 18.
} 
memahami fenomena komunikasi yang kemudian menjadi sebuah ilmu yang dipelajari di berbagai perguruan tinggi ${ }^{5}$.

Secara terminologis (istilah para ahli), komunikasi dapat dipahami sebagaimana pendapat Ruben dalam bukunya communication and human behavior, yang dikutip oleh Susanto menyebutkan bahwa komunikasi adalah suatu proses bagaimana kita bisa memahami dan dipahami oleh orang lain, dan komunikasi merupakan proses yang dinamis dan secara konstan berubah sesuai dengan situasi yang berlaku ${ }^{6}$. Sementara, Everett M. Rogers dan Lawrence Kincaid menyatakan bahwa komunikasi adalah suatu proses dimana dua orang atau lebih melakukan pertukaran informasi antara satu dengan lainnya, yang pada gilirannya terjadi saling pengertian yang mendalam. Dan menurut Harold D. Lasswell, bahwa cara terbaik untuk menjelaskan komunikasi adalah dengan menjawab pertanyaan berikut : Who Says What In Which Channel To Whom With What Effect (Siapa Mengatakan Apa dengan Saluran Apa Kepada Siapa dengan Efek Bagaimana) ${ }^{7}$.

Definisi di atas tentu belum bisa mewakili beragamnya pemahaman tentang komunikasi, oleh karena itu Mulyana menjelaskan sebagaimana pandangan yang dikemukakan oleh John R. Wenburg dan William W. Wimot, juga Kenneth K. Sereno dan Edward M. Bodaken menyebutkan, bahwa untuk memahami komunikasi secara utuh Setidaknya ada 3 (tiga) kerangka pemahaman mengenai komunikasi, yaitu : Komunikasi sebagai tindakan satu arah, komunikasi sebagai tindakan interaksi, dan komunikasi sebagai transaksi ${ }^{8}$.

Komunikasi sebagai tindakan satu arah adalah komunikasi yang mengisyaratkan penyampaian pesan searah dari seseorang atau suatu lembaga kepada orang lain atau sekelompok orang lainnya, baik secara langsung (tatap

\footnotetext{
${ }^{5}$ Cangara, Komunikasi Politik; Konsep, Teori dan Strategi, (Jakarta : Raja Grafindo Persada, 2009), h. 19.

${ }^{6}$ Susanto, Komunikasi Politik dan Otonomi Daerah, (Jakarta : Mitra Wacana Media, 2009), h. 2.

${ }^{7}$ Wiryanto, Pengantar Ilmu Komunikasi, (Jakarta: Grasindo, 2004), h.6-7. 67.

${ }^{8}$ Deddy Mulyana, Ilmu Komunikasi Suatu Pengantar, (Bandung : Rosdakarya, 2007), h.
} 
muka) ataupun melalui media, seperti surat kabar, majalah, radio, atau televisi. Pemahaman komunikasi satu arah ini berorientasi kepada sumber atau komunikator. Sedangkan, komunikasi sebagai tindakan interaksi adalah komunikasi yang saling mempengaruhi antara komunikator dengan komunikan, komunikasi ini lebih bersifat sebab-akibat atau aksi-reaksi. Dan bentuk komunikasi ini dipandang sedikit lebih dinamis daripada komunikasi sebagai tindakan satu arah. Dalam pemahaman komunikasi interaksi ini terdapat unsur umpan balik (feed back), selain 5 (lima) unsur yang telah disebutkan di atas. Umpan balik merupakan respon dari apa yang telah disampaikan dan akan mempengaruhi perilaku komunikasi selanjutnya. Konsep umpan balik dari penerima (pertama) ini sebenarnya sekaligus merupakan pesan penerima (yang berganti peran sebagai pengirim kedua).

Konsepsi komunikasi sebagai transaksi adalah komunikasi yang pada dasarnya adalah suatu proses dinamis yang secara berkesinambungan mengubah pihak-pihak yang berkomunikasi. Berdasarkan pandangan ini, orang-orang yang berkomunikasi adalah komunikator-komunikator yang aktif mengirim dan menafsirkan pesan. Setiap pihak dianggap sumber dan sekaligus juga penerima pesan, setiap saat mereka bertukar pesan baik verbal maupun non verbal. Hal tersebut menunjukkan bahwa Istilah transaksi mengisyaratkan bahwa pihak-pihak yang berkomunikasi berada dalam keadaan interdepedensi atau timbal balik; eksistensi satu pihak ditentukan oleh eksistensi pihak lainnya ${ }^{9}$.

Ketiga konsepsi tentang komunikasi sebagaimana dikemukakan di atas, tentu belum mewakili semua defenisi yang telah dibuat oleh para ahli tentang komunikasi. Namun, paling tidak telah nampak gambaran umum tentang apa yang dimaksud komunikasi, yang menunjukkan bahwa komunikasi sebagai ilmu sosial merupakan sebuah proses interaksi tentang bagaimana sesorang atau khalayak memahami, tukar menukar dan menginterpretasikan pesan dalam proses komunikasi. Kompleksitas komunikasi yang terjadi dalam kehidupan manusia harus mampu dijelaskan secara konfrehensif dengan berbagai pendekatan yang

\footnotetext{
${ }^{9}$ Ibid, h. 67-77.
} 
ada. Sebagaimana yang diungkapkan Littlejohn ; Communication involves understanding how people be have in creating, exchanging, and interpreting messages. Consequently, comunication inquiry combines both scintific and humanistic methods ${ }^{10}$.

Pandangan tersebut di atas juga didukung oleh Shannon dan Weaver yang mengemukan bahwa komunikasi adalah bentuk interaksi manusia yang saling mempengaruhi satu sama lain, sengaja maupun tidak disengaja dan tidak terbatas pada bentuk komunikasi verbal, tetapi juga dalam hal ekspresi wajah, lukisan, seni dan teknologi ${ }^{11}$.

Berkomunikasi bagi manusia adalah sebagai upaya untuk membangun pemahaman yang sama tentang sesuatu, dan disisi yang lain menunjukkan bahwa seseorang berkomunikasi berarti mengharapkan agar orang lain dapat ikut berpartisipasi atau bertindak sama sesuai dengan tujuan, harapan atau isi pesan yang disampaikan. Dalam hal ini Prof. Wilbur Schramm mengungkapkan : "When we communication, we are trying to establish a commoness with someone. That is we are trying to share informasion, an idea or on attitude, communication always requires at least three elements : the source, the message and destination ${ }^{12, "}$

Pandangan Wilbur Schramm tersebut menekankan bahwa dengan berkomunikasi berarti kita berusaha untuk mengadakan persamaan atau commness dengan orang lain, dengan cara menyampaikan dan menerima ide-ide, gagasangagasan yang dituangkan dalam lambang-lambang tertentu yang sudah diberi pengertian yang sama. Atas dasar ini, komunikasi menunjukkan suatu proses pengoperan lambang-lambang yang berarti dengan tujuan untuk mempengaruhi sikap maupun tingkah laku orang lain agar bertindak sesuai dengan yang diinginkan.

${ }^{10}$ Littlejohn, Theories Of Human Communication, (Belmont : Wadsworth Publishing Company, 1999), h. 12.

${ }_{11}^{11}$ Wiryanto, Pengantar Ilmu Komunikasi, (Jakarta: Grasindo, 2004), h. 7.

${ }^{12}$ Schramm, The Process and Effect Of Mass Communication, (Urbajuna : University Of Lilinois Pres 1995), h. 3. 
Komunikasi manusia menunjukkan sebuah proses interaksi sosial yang dilatarbelakangi oleh motif-motif tertentu sebagai upaya untuk terus mempertahankan keberlangsungan hidupnya sebagai mahluk individu dan mahluk sosial. Dalam konteks hubungan komunikasi manusia menunjukkan saling ketergantungan satu dengan manusia lainnya. Dalam teori pertukaran sosial, menjelaskan bahwa interaksi manusia digambarkan sebagai suatu transaksi ekonomi; dengan asumsi bahwa dalam interaksi sosialnya orang berupaya untuk memaksimalkan imbalan dan meminimalkan biaya. Jika pertukaran sosial ini diterapkan pada penetrasi sosial, maka orang akan mengungkapkan informasi mengenai dirinya bila risiko biaya-imbalan bisa diterima. Jika imbalan yang diterima semakin besar dan biaya semakin berkurang, maka hubungan antar individu semakin dekat dan intim, dan mereka masing-masing akan lebih banyak memberikan informasi tentang diri mereka masing-masing ${ }^{13}$.

Secara lebih spesifik dapat dijelaskan faktor-faktor yang mendasari maupun yang mendorong manusia berkomunikasi, yaitu antara lain : Pertama, manusia berkomunikasi untuk membangun konsep dirinya, aktualisasi diri, untuk tetap menjaga kelangsungan hidupnya, terhindar dari tekanan dan ancaman dan ketegangan dalam dirinya serta keinginan memupuk hubungan baik dengan orang lain. Kedua, manusia berkomunikasi sebagai instrumen pengungkapan perasaanperasaan (emosi) dalam dirinya. Seperti ungkapan rasa sayang, peduli, simpati, rindu, gembira, sedih, marah takut dan sebagainya. Ketiga, manusia berkomunikasi sebagai upaya mempertahankan dan menegaskan komitmenkomitmennya terhadap tradisi keluarga, suku, ideologi, dan agama mereka. Keempat, komunikasi dilakukan manusia sebagai upaya mendidik, mendorong, mengubah sikap dan keyakinan, mengubah perilaku atau menggerakkan tindakan, dan juga dilakukan untuk menghibur. Sehingga komunikasi dilakukan sebagai sebuah instrumen untuk mencapai tujuan-tujuan tertentu ${ }^{14}$.

13 Morissan, Teori Komunikasi : Individu Hingga Massa; Edisi Pertama, (Jakarta, Kencana Prenada Media Group, 2013), h. 298.

${ }^{14}$ Mulyana, Ilmu Komunikasi, h. 5-8. 


\section{Komunikasi Dalam Pandangan Islam}

Islam secara bahasa berasal dari kata salima yang berarti selamat sentosa. Dari asal kata itu aslama yang artinya memelihara dalam keadaan selamat sentosa. Dalam pengertian yang lain diartikan sebagai sikap menyerahkan diri, patuh, tunduk dan taat. Sehingga seseorang yang bersikap sebagaimana dimaksud oleh pengertian Islam disebut muslim, yaitu orang yang telah menyatakan dirinya patuh, tunduk dan taat kepada Allah SWT. Secara terminologis, Islam adalah ajaran-ajaran yang diwahyukan Tuhan kepada manusia melaui Rasul-Nya, dari Nabi Adam sampai Nabi Muhammad SAW sebagai Nabi dan Rasul terakhir ${ }^{15}$.

Islam dalam hal ini, dimaksudkan sebagai agama yang ajaran-ajarannya diwahyukan Allah SWT kepada manusia melalui Nabi Muhammad SAW. Sebagai nabi dan rasul terakhir penyempurna ajaran-ajaran sebelumnya. Islam pada hakekatnya membawa ajaran-ajaran tentang seluruh aspek kehidupan manusia, sehingga Islam dinyatakan sebagai agama rahmat bagi seluruh alam. Hal itu menunjukkan bahwa Islam tidak hanya sekedar bicara tentang hubungan transenden antara manusia dengan sang pencipta (Allah SWT) lewat prilaku ritual dan ibadah formal. Namun lebih dari itu Islam merupakan ajaran moral yang menekankan tentang bagaimana mewujudkan keadilan, kejujuran, kebersamaan, kedamaian dan sebagainya yang menunjukkan penekanannya pada hubungan sesama manusia (hablum minanas.). Yaitu bagaimana manusia saling berinteraksi dan berkomunikasi sesamanya dalam membangun hubungan sosial, ekonomi, politik dan sebaginya. Yang dengan tegas memberi petunjuk dan rambu-rambu kehidupan bagi manusia. Tentang, mana yang boleh dan mana yang tidak, mana yang baik dan mana yang buruk. Seperti halnya rambu-rambu lalu lintas di jalan yang memberikan panduan bagi seluruh pengguna jalan dengan tujuan untuk keselamatan pengguna jalan dan kemudahan berlalu lintas secara keseluruhan ${ }^{16}$.

Dengan demikian maka setiap pemeluk Islam harus menyadari bahwa AlQuran dan sunnah Nabi SAW adalah pedoman utama bagi mereka dan tidak

\footnotetext{
${ }^{15}$ Nata, Al-Quran dan Hadits, (Jakarta : Raja Grafindo Persada, 1993), h. 23-24. 16 Shihab, Membumikan Al Quran, (Bandung : Mizan, 2003), h. 28.
} 
menjadikan yang lain sebagai pedoman maupun tuntunan dalam kehidupan sebagai seorang muslim. Lebih dari itu, bahwa setiap sikap dan perilaku dalam kehidupan pribadi dan kehidupan sosialnya harus senantiasa berdasarkan pada AlQuran dan sunnah Nabi SAW. Konsekuensi ini merupakan tuntunan Allah SWT kepada manusia agar dapat mencapai kualitas hidup bahagia di dunia dan akhirat.

Dalam Islam, komunikasi dianggap sebagai fitrah manusia. Manusia telah Allah lebihkan dari mahluk lainnya dalam segi komunikasi, dalam Al-Quran hal itu dijelaskan dengan kata "Albayan" (pandai berbicara) yang terdapat pada surah Ar-Rahman ayat 1-4. Asy-Syaukani dalam tafsir Fath Al-Qodir mengartikan albayan sebagai kemampuan berkomunikasi, dengan kemampuan tersebut manusia menjadi mahluk yang dinamis dan terus berkembang berdasarkan kemampuan dan kebutuhannya dalam berkomunikasi ${ }^{17}$. Sehingga sangat tepat kiranya ungkapan bahwa manusia tidak bisa tidak berkomunikasi, dan $75 \%$ waktu yang dimiliki manusia telah dihabiskan untuk berkomunikasi.

Dalam perspektif Islam, komunikasi dilakukan sebagai upaya mewujudkan hubungan secara vertikal dengan Allah swt, melalui ibadah-ibadah fardhu (sholat, puasa, zakat dan haji, dsb). Dan disisi yang lain komunikasi dilakukan untuk membangun hungan horizontal yaitu hubungan dengan sesama manusia, yaitu dalam rangka melakukan kegiatan muamalah dalam bidang-bidang ekonomi, sosial, budaya, politik dan sebagainya. Dan hubungan yang dibangun tersebut secara vertikal dan horizontal adalah sebagai upaya untuk memenuhi kebutuhan manusia secara lahir dan batin. Sehingga komunikasi dalam Islam sebagai upaya untuk mewujudkan keseimbangan dan kebaikan dalam hidup manusia.

Keberhasilan dakwah yang dilakukan oleh Rasul SAW, jika dikaitkan dengan komunikasi maka Rasul Muhammad SAW adalah seorang komunikator yang handal dalam menyampaikan pesan-pesan keagamaan (Islam) melalui berbagai pendekatan yang efektif sehingga agama Islam selama 23 tahun, melalui dakwah nabi telah mampu menyebarkan Islam ke berbagai penjuru dunia, dan sampai sekarang ajarannya tetap dijaga dan diamalkan dalam kehidupan pribadi

17 Saefullah, Kapita Selekta Komunikasi : Pendekatan Budaya dan Agama, (Bandung : Simbiosa Rekatama Media, 2007), h. 67. 
dan kehidupan sosial. Sehingga, Rasul Muhammad SAW senantiasa menjadi contoh (uswah) umat dalam segala hal, termasuk juga kita mencontoh Rasul SAW dalam berkomunikasi. Sehingga telah jelas bagi kita bahwa Komunikasi dalam Islam merupakan suatu aktivitas yang sangat sentral dan penting untuk diperhatikan sesuai petunjuk alquran maupun sunnah Nabi SAW. Hal tersebut mengisyaratkan bahwa berkomunikasilah dengan baik, bermanfaat, didasarkan pada etika yang baik, untuk kebaikan pribadi dan masyarakat.

\section{Nilai-nilai Etika Komunikasi Islam}

Manusia sebagai mahluk sosial, satu dengan yang lainnya saling berhubungan dan berinteraksi untuk memenuhi kebutuhan yang konpleks. Dalam pergaulan hidup bermasyarakat, berbangsa, bernegara, hingga pergaulan hidup tingkat internasional diperlukan suatu sistem yang mengatur bagaimana seharusnya manusia berinteraksi, atau bergaul maupun berkomunikasi. Sistem pengaturan pergaulan dimaksud menjadikan suasana saling menghormati dan menghargai satu dengan lainnya, yang dalam tradisi masyarakat kita dikenal dengan sebutan sopan santun, tata krama, protokoler dan sebagainya. Tujuan dari sistem tersebut tidak lain untuk menjaga kepentingan, harga diri dan kehormatan masing-masing dalam pergaulan sehingga mereka merasa aman, nyaman, tentram, terlindung tanpa merugikan kepentingannya serta terjamin bahwa setiap perbuatan yang dilakukannya sesuai dengan adat kebiasaan yang berlaku di tengah masyarakatnya dan tidak bertentangan dengan hak asasi umumnya. Hal itulah yang mendasari tumbuh kembangnya etika di tengah masyarakat.

Secara etimologi (bahasa) "etika" berasal dari bahasa Yunani, yaitu Ethos. Dalam bentuk tunggal ethos diartikan sebagai tempat tinggal yang biasa, padang rumput, kandang, adat, akhlak, perasaan, cara berpikir. Sementara dalam bentuk jamak ta etha berati adat kebiasaan ${ }^{18}$. Etika dalam bahasa inggris disebut ethic (singular) yang berarti a system of moral principles or rules of behaviour (suatu sistem, prinsip moral, atau aturan berperilaku) ${ }^{19}$. Sementara dalam Kamus Besar

\footnotetext{
${ }^{18}$ Muhammad Mufid, Etika dan Filsafat Komunikasi (Jakarta: Kencana, 2010), h. 173.

${ }^{19}$ Ayi Sofyan, Etika Politik Islam (Bandung: Pustaka Setia, 2012), h. 37.
} 
Bahasa Indonesia, etika diartikan sebagai: Ilmu tentang apa yang baik dan apa yang buruk dan tentang hak dan kewajiban moral (akhlak); Kumpulan asas dan nilai yang berkenaan dengan akhlak; nilai mengenai benar dan salah yang dianut suatu golongan atau masyarakat.

Dalam kehidupan sehari-hari kata etika berkaitan erat dengan kata moral, yang keduanya menunjukkan suatu nilai hidup yang dianut suatu masyarakat. Kata moral sendiri berasal dari bahasa latin yaitu mos dan dalam bentuk jamaknya mores yang berarti juga adat kebiasaan atau cara hidup seseorang dengan melakukan perbuatan yang baik (kesusilaan) dan menghindari perbuatan yang buruk. Meskipun nampak sama antara etika dan moral, namun perbedaannya terletak pada bentuknya. Moral atau moralitas untuk penilaian perbuatan yang dilakukan, sedangkan etika yaitu untuk pengkajian sistem nilai-nilai yang berlaku. Istilah lain yang identik dengan etika, yaitu: Susila (bahasa sangsekerta) menunjukan kepada dasar-dasar, prinsip, aturan hidup (sila) yang lebih baik (su). Etika juga disebut akhlak (bahasa Arab) ${ }^{20}$.

Etika bagi filusuf sering disebut sebagai filsafat moral. Etika merupakan cabang filsafat yang membahas mengenai tindakan manusia dalam kaitannya dengan tujuan utama hidupnya. Pembahasan etika seputar baik-buruk atau benartidaknya tingkah laku dan tindakan manusia serta menyoroti kewajiban-kewajiban manusia. Dalam hal ini etika mempersoalkan bagaimana manusia seharusnya berbuat atau bertindak. Tindakan yang dilakukan manusia ditentukan atau didasarkan oleh bermacam-macam norma (aturan) yang telah disepakati dalam suatu masyarakat. Dalam hal ini etika membantu manusia untuk mengambil sikap terhadap semua norma yang ada baik dari dalam dan dari luar, supaya manusia mencapai kesadaran moral yang otonom ${ }^{21}$.

Menurut H.A. Mustafa, etika sebagai ilmu yang menyelidiki terhadap perilaku mana yang baik dan yang buruk dan juga dengan memperhatikan perbuatan manusia sejauh apa yang telah diketahui oleh akal pikiran. Sementara

\footnotetext{
${ }^{20}$ Mukhtar Latif, Filsafat Ilmu (Jakarta: Kencana, 2014), h. 276.

${ }^{21}$ Muhammad Mufid, Etika dan Filsafat Komunikasi (Jakarta: Kencana, 2010), h. 174.
} 
W.J.S. Poerwadarminto menjelaskan bahwa etika sebagai ilmu pengetahuan mengenai asas-asas atau dasar-dasar moral dan akhlak. Hal yang sama juga disebutkan oleh Ahmad Amin yang mendefinisikan etika sebagai sebuah ilmu yang menjelaskan tentang arti baik dan buruk serta apa yang seharusnya oleh manusia, juga menyatakan sebuah tujuan yang harus dicapai manusia dalam perbuatannya dan menunjukkan arah untuk melakukan apa yang seharusnya dilakukan oleh manusia ${ }^{22}$.

Dari penjelasan di atas tentang pengertian etika, baik secara etimologi maupun terminologi menunjukkan bahwa etika merupakan sebuah ilmu untuk mengetahui dan menilai sesuatu tindakan atau perilaku manusia berdasarkan suatu penilaian yang didasarkan oleh akal pikiran manusia, apakan hal itu baik atau hal itu tidak baik (buruk) untuk menjelaskan perilaku atau perbuatan manusia. sesuatu yang dilakukan baik, maka secara etika menunjukkan bahwa orang yang melakukannya dikatanya beretika, sebaliknya jika perbuatan yang dilakukan tidak baik (buruk) maka orang yang melakukannya dikatakan tidak beretika.

Pada uraian di atas telah diungkapkan pengertian komunikasi dan etika, selanjutnya penulis ingin menyamakan pemahaman kita tentang etika komunikasi. Etika komunikasi adalah sebuah nilai, norma atau ukuran-ukuran tingkah laku yang dianggap baik dalam kegiatan komunikasi di tengah-tengah masyarakat. Masyarakat satu dengan lainnya tentulah memiliki perbedaan sebagai standart atau ukuran-ukuran terhadap tingkah laku, norma maupun nilai yang dianggap baik dan buruk. Perbedaan tersebut sebagai suatu keniscayaan didasarkan pada perbedaan budaya masing-masing.

Terdapat berbagai perspektif dalam penilaian tentang etika komunikasi, sebagaimana Richard L. Johannesen dalam Aan Ridwan menyebutkan tujuh perspektif etika komunikasi, yaitu: Perpektif politik (nilai demokrasi, keterbukaan, kebebasan yang disertai tanggung jawab, penghormatan terhadap hak-hak individual); Perspektif sifat manusia (motif komunikator, sifat dari cara-cara yang

${ }^{22}$ http: Seputarpengetahuan.com, 15 Pengertian Etika Menurut Para Ahli (diakses pada tanggal 13 Desember 2015). 
diambil, keadaan yang mengiringi); Perspektif dialogis (nilai kebersamaan, keterbukaan hati, kelangsungan, kejujuran, spontanitas, tidak berpura-pura, dan sebagainya); Perspektif situasional (peran komunikator terhadap khalayak, standar khalayak mengenai kelogisan dan kelayakan, derajat kesadaran khalayak, tingkat urgensi untuk pelaksanaan usulan komunikator, tujuan dan nilai khalayak); Perspektif religius (pendekatan normatif kitab suci, pahala dan dosa); Perspektif utilitarian (nilai kegunaan, kesenangan, kegembiraan), dan Perspektif legal (nilai hukum yang berlaku).

Dalam pembahasan ini, penulis mencoba menguraikan etika komunikasi berdasarkan perspektif religius, yaitu etika komunikasi berdasarkan alquran dan sunnah Nabi Saw atau dengan sebutan lain yaitu etika komunikasi islami. Hal tersebut didasarkan pada keyakinan bahwa doktrin-doktrin (ajaran) Islam sebagai agama yang membawa nilai universal yang mengandung kebenaran dan kebaikan bagi seluruh umat manusia. komunikasi islami dapat dipahami sebagai suatu proses kegiatan menyampaikan pesan atau informasi dari komunikator kepada komunikan dengan menggunakan prinsip maupun kaidah komunikasi yang terdapat di dalam alquran maupun sunnah Nabi SAW.

Berdasarkan pendekatan di atas dalam hal ini etika komunikasi islami dimaksudkan sebagai sebuah nilai-nilai yang baik yang pantas dan memiliki manfaat ketika melakukan proses komunikasi, apakah komunikasi itu berupa komunikasi interpersonal, komunikasi kelompok, komunikasi organisasi atau komunikasi massa kesemua bentuk komunikasi yang akan dilakukan tersebut harus didasarkan pada nilai-nilai alquraan dan sunnah Nabi SAW.

Secara umum, nilai-nilai universal sebagai sebuah etika komunikasi islami antara lain adalah:

\section{Kejujuran (Nilai Jujur) berkomunikasi}

Aspek kejujuran atau objektivitas dalam berkomunikasi merupakan sebuah nilai yang sangat penting untuk dijunjung tinggi dan diterapkan dalam proses kegiatan komunikasi. Dalam alquran kejujuran ini disebut dengan istilah amanah, ghair al-takzib, shidq, al-haq, sehingga seorang komunikator dalam 
menyampaikan pesan dilarang untuk berdusta atau mengada-ada suatu informasi yang sebenarnya tidak ada, gosip atau cerita palsu (bosong belaka) ${ }^{23}$. Dalam alquran disebutkan pada surah An Nahl ayat 105 "sesungguhnya yang mengadaadakan kebohongan, hanyalah orang-orang yang tidak beriman kepada ayat-ayat Allah, dan mereka itulah orang-orang pendusta”.

Lawan kata dari jujur (benar) adalah dusta atau bohong. Berdusta adalah menyatakan sesuatu yang tidak sesuai dengan kenyataan sebenarnya. Dusta dalam Islam sangat dilarang, karena perbuatan tersebut selain merugikan orang lain juga akan merugikan diri sendiri. Dalam Al-Quran telah disebutkan bahwa pada hari kiamat orang-orang yang berbuat dusta terhadap Allah, muka mereka menjadi hitam dan mereka sebagai penghuni neraka (QS Az-Zumar: 60). Sebaliknya Islam sangat menghargai orang-orang yang bersifat jujur dan benar ucapannya walaupun dalam bercanda mereka orang-orang yang senantiasa menjaga kejujurannya Allah dan Rasul-Nya menjamin kepada mereka surga.

Dalam interaksi sehari-hari, tentulah kita tidak luput terhadap canda dan tawa sebagai bagian dari "bunga-bunga komunikasi", dan biasanya orang-orang suka melebih-lebihkan candanya untuk mengundang gelak tawa orang yang diajak bercanda. Hal itu terkadang dibuat sedemikian rupa dan dengan berbagai cara terdakang juga dilakukan dengan harus berbohong dan mengada-ngada cerita. Hal seperti itu, dengan tegas dinyatakan bahwa Islam tidak membolehkan hal yang demikian dan termasuk kepada perbuatan yang dilarang ${ }^{24}$.

"Jauhi dusta" karena dusta membawa kamu kepada dosa dan dosa membawa kamu pada neraka, sebaliknya perkataan jujur akan membawa kamu kepada kebajikan, dan akan membawa kamu ke surga. Kejujuran pada hakekatnya menumbuhkan kekuatan, dan kebohongan melahirkan kelemahan. Orang-orang yang selalu jujur baik dalam perkataan maupun perbuatan akan selalu merasakan kehidupan yang nyaman dan damai dalam dirinya dan dipastikan apa yang

${ }^{23}$ Syukur Kholil, Komunikasi Islam (Bandung: Ciptapustaka Media, 2007), h. 2.

${ }^{24}$ Syafe'i, Al Hadis : Aqidah, Akhlak, Sosial dan Hukum, (Bandung : Pustaka Setia, 2000), h. 77. 
diucapkan maupun diperbuatnya tidak akan membawa mudhorat bagi orang lain dan lingkungannya. Dan benar merupakan salah satu sifat Nabi SAW yang semestinya kita teladani dalam hidup ${ }^{25}$.

Orang-orang yang membiasakan dirinya dengan kata-kata dusta dalam pergaulan dengan sesama maka bagi orang tersebut dianggap sebagai golongan orang-orang yang munafiq, sebagaimana dinyatakan Nabi SAW dalam sebuah hadis yang diriwayatkan oleh Bukhari dan Muslim bahwa : "Tanda-tanda orang munafiq ada tiga. Jika ia berkata, ia berdusta; Jika berjanji, ia menyalahi; dan jika dipercaya ia berkhianat”

Menurut Alfred Korzyibski sebagaimana yang dikutip Jalaludin Rakhmat menyebutkan bahwa penyakit jiwa individual maupun sosial timbul karena menggunakan bahasa yang tidak benar. Semakin gila seseorang, makin cenderung ia menggunakan kata-kata yang salah atau kata-kata yang menutupi kebenaran. Dalam komunikasi dikenal dua cara untuk menutupi atau meyembunyikan kebenaran, yaitu pertama dengan menggunakan kata-kata yang abstrak, ambigu, atau menimbulkan penafsiran yang sangat berlainan. Sebagai contoh apabila seseorang tidak setuju dengan pandangan anda, maka anda lantas mengatakan bahwa orang tersebut tidak pancasilais. Cara yang kedua menciptakan istilah yang diberi makna orang lain, dengan memutarbalikkan makna sama sekali, istilah ini dikenal dengan eufemisme. Sebagai contoh harga-harga tidak dinaikkan melainkan disesuaikan, kasus kekurangan gizi disebut dengan istilah rawan pangan, judi yang dibuat pemerintah disebut dengan istilah sumbangan dana sosial berhadiah (SDSB) dan lain sebagainya ${ }^{26}$.

Ungkapan di atas kembali dikuatkan dengan ungkapan hadis berikut :

${ }^{25}$ Saefullah, Kapita Selekta Komunikasi: Pendekatan Agama dan Budaya, (Bandung, Simbiosa Rekatama Media, 2007), h. 70.

26 Rahmat, Prinsip-prinsip Komunikasi menurut Al-Quran : Makalah (http://sumut.kemenag.go.id/. 


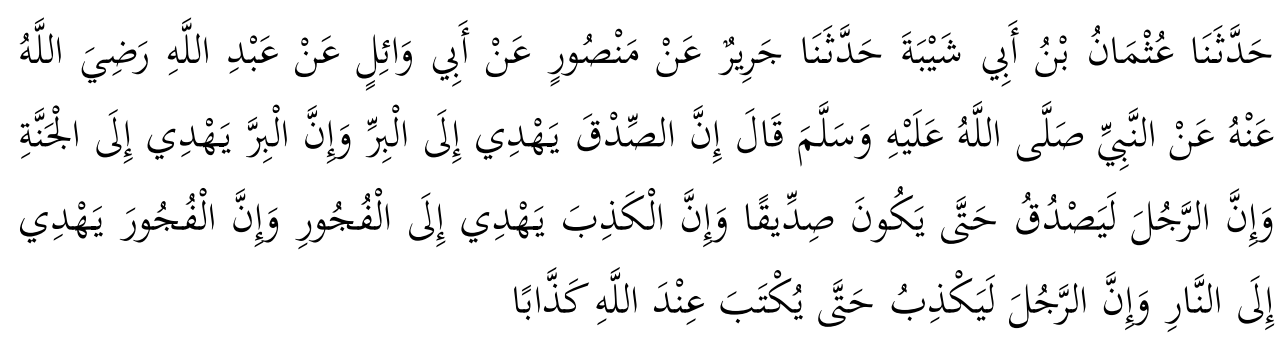

Artinya : Sesungguhnya benar (jujur) itu menuntun kepada kebaikan, dan kebaikan itu menuntun kepada surga, dan seorang itu berlaku benar sehingga tercatat disisi Allah sebagai seorang yang sidiq (yang sangat jujur dan benar). Dan dusta menuntun kepada curang, dan curang itu menuntun kepada neraka. Dan seorang pendusta sehingga tercatat di sisi Allah sebagai pendusta (Riwayat Bukhari). ${ }^{27}$

Hadis tersebut dalam konteks komunikasi memberi penjelasan bahwa berkomunikasilah dengan benar atau jujur, karena hal itu akan membawa kebaikan dan keberuntungan bagi yang melakukan dan juga membawa kemaslahatan bagi orang lain. Maka, Nabi SAW telah mengajarkan kita untuk selalu mawas dari perkataan yang dusta, karena akan membawa kepada kerugian yang nyata.

Dalam komunikasi islami pemahaman jujur dalam berkomunikasi meliputi nilai keadilan yaitu bagaimana menempatkan komunikasi pada tempatnya. Selain itu, adil juga bermakna bahwa komunikasi itu semestinya harus ditempatkan pada nilai kewajaran dan kepatutan sesuai dengan kondisi masyarakat dimana komunikasi itu berlangsung.

\section{Katakan yang baik atau Diam (Falyakul Khairan au liyasmut)}

Prinsip Falyakul Khairan au liyasmut (katakan yang baik atau diam), dapat kita jumpai di dalam kitab-kitab hadis yang ditulis oleh imam-imam hadis. Dari penelusuran penulis menemukan tema tersebut di dalam kitab hadis imam Bukhori sebanyak 7 hadis termasuk salah satunya yang telah disebutkan di atas. Selanjutnya terdapat 5 hadis di dalam kitab Imam Muslim, dan 1 hadis di dalam kitab Imam Malik, dan juga terdapat 2 hadis yang bermakna sama di dalam kitab Imam Ibnu Majah.

\footnotetext{
${ }^{27}$ Ibid, h. 82.
} 
Hadis yang berkaitan dengan hal tersebut adalah sebagai berikut :

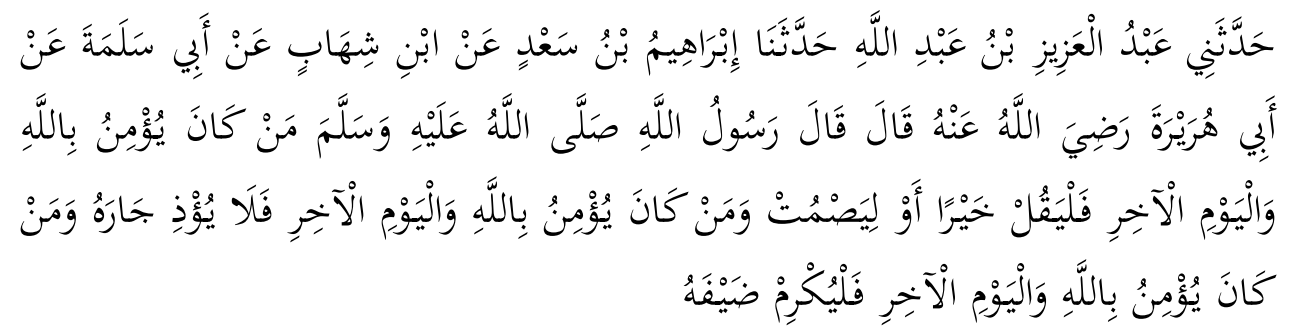

Artinya : Telah menceritakan kepada kami Abdul Aziz bin Abdullah, telah menceritakan kepada kami Ibrahim bin Sa'd dari Ibnu Syihab dari Abu Salamah dari Abu Hurairah radliallahu 'anhu dia berkata; Rasulullah shallallahu 'alaihi wasallam bersabda: "Barangsiapa beriman kepada Allah dan hari akhir hendaknya ia berkata baik atau diam, dan barangsiapa beriman kepada Allah dan hari Akhir, janganlah ia menyakiti tetangganya, dan barang siapa beriman kepada Allah dan hari Akhir, hendaknya ia memuliakan tamunya." (Hadis di atas adalah hadis yang diriwayatkan oleh Imam Bukhori, dengan nomor hadis 5994 dalam kitab hadis Imam Bukhori. Hadis tersebut dikelompokkan ke dalam pembahasan tentang iman). ${ }^{28}$

Dalam konteks komunikasi setidaknya perintah yang pertama pada hadis di atas secara jelas memerintahkan kepada kita untuk membangun komunikasi yang baik. Ucapan yang baik merupakan salah satu dari bentuk komunikasi yang baik. Ucapan yang baik itu adalah ucapan yang mempunyai nilai mamfaat dan ucapan yang berkualitas. Untuk menghasilkan kualitas perkataan yang baik maka setiap muslim hendaknya memperhatikan beberapa prinsip berikut : pertama, Pikirkan terlebih dahulu materi yang akan dibicarakan, kedua, perhatikan siapa lawan kita bicarak ketiga, memahami waktu yang tepat untuk berbicara dan berhenti, Keempat, memiliki argumen yang kuat dan akurat terhadap materi atau ucapan yang kita sampaikan. kelima, gunakan etika yang baik dalam menyampaikan ucapan tersebut. Keenam, gunakan bahasa yang sederhana dan mudah dimengerti ${ }^{29}$.

Perkataan yang baik tentunya akan tetap dijaga bagi mereka yang beriman kepada Allah dengan sebenar-benarnya tentu dia takut kepada ancaman-Nya, mengharapkan pahala-Nya, bersungguh-sungguh melaksanakan perintah dan meninggalkan larangan-Nya. Yang terpenting dari semuanya itu ialah

\footnotetext{
28 Program Hadis Digital.

${ }^{29}$ Munir, Metode Dakwah, (Jakarta : Kencana, 2006) , h.117
} 
mengendalikan gerak-gerik seluruh anggota badannya karena kelak dia akan dimintai tanggung jawab atas perbuatan semua anggota badannya, sebagaimana tersebut pada firman Allah : "Sesungguhnya pendengaran, penglihatan, dan hati semuanya kelak pasti akan dimintai tanggung jawabnya”. (QS. Al Isra' : 36), “Apapun kata yang terucap pasti disaksikan oleh Raqib dan 'Atid”. (QS. Qaff : 1)

Bahaya lisan itu sangat banyak. Sebagaimana hadis Rasulullah SAW : "Bukankah manusia terjerumus ke dalam neraka karena tidak dapat mengendalikan lidahnya”. Tentunya mereka yang memahami hal ini dan beriman kepada-Nya dengan keimanan yang sungguh-sungguh, maka ia akan memelihara lidahnya sehingga dia tidak akan berkata kecuali perkataan yang baik atau diam.

Diam dalam komunikasi Islam merupakan salah satu strategi dalam berkomunikasi. Dia dianggap sikap yang baik dalam menghadapi suatu kondisi tertentu yang mengharuskan seseorang untuk diam, dan dia tersebut lebih baik dari ucapan-ucapan indah sekalipun.

Setidaknya setiap muslim dalam berkomunikasi mengetahui kapan dia harus berbicara dan kapan dia harus diam. Sikap diam dalam komunikasi diperlukan setidaknya dalam menghadapi empat kondisi yaitu : menghindari konfrontasi, disaat perkataan sudah tidak efektif, dalam rangka menyusun taktik dan strategi, diam dalam arti membangun komunikasi nonverbal yaitu komunikasi dengan perbuatan tidak dengan kata-kata. Akan tetapi tidak setiap diam itu emas dan bicara itu perak, dalam pribahasa yang mungkin sering kita dengar. Diam juga ternyata menimbulkan dosa bagi setiap muslim yang melakukan yaitu diam ketika kemungkaran dilakukan secara terang-terangan, diam itu dosa jika berkenaan dengan informasi yang diperlukan masyarakat kita tetap diam tidak mau menyampaikan atau dengan kata lain menyembunyikan informasi yang dibutuhkan masyarakat, diam itu dosa apabila kita tidak mau mengakui kesalahan sendiri, diam itu dosa adalah tidak mau berbicara selama tidak berkaitan dengan keuntungan dirinya sendiri ${ }^{30}$.

\footnotetext{
${ }^{30}$ Munir, Metode Dakwah, (Jakarta : Kencana, 2006) , h.118-123
} 


\section{Cermat dan akurat dalam berkomunikasi (Tabayyun)}

Kehidupan manusia dilingkupi dengan lautan informasi yang sangat banyak dan sangat beragam bentuknya. Oleh karena itu diperlukan kecermatan dan keakuratan dalam menerima dan meneruskan atau melanjutkan komunikasi (pesan atau berita atau informasi yang diterima). Menyampaikan pesan secara tepat merupakan nilai yang penting untuk diperhatikan seorang komunikator, sehingga komunikasi yang dilakukan tidak mengakibatkan kesalahan yang bisa berakibat pada timbulnya konflik dan bencana terhadap diri pribadi maupun masyarakat secara luas.

Untuk mencapai ketepatan data maupun fakta sebagai bahan informasi yang akan disampaikan kepada orang lain atau masyarakat luas diperlukan terlebih dahulu pemeriksaan secara seksama oleh komunikator. Hal ini penting karena banyak masyarakat khususnya di daerah pedesaan mempercayai informasi dari pemuka masyarakat (opinion leaders) sebagai sebuah kebenaran. Dalam alquran hal ini disebut dengan tabayun dan hal itu diungkapkan dalam alquran surah al hujarat ayat 6 .

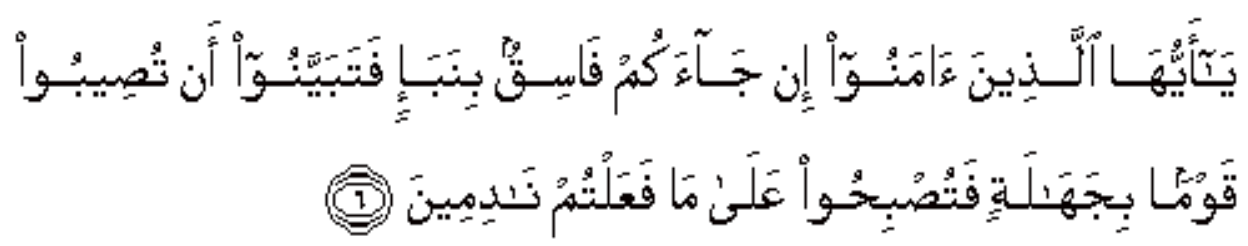

"Wahai orang-orang yang beriman, jika datang kepadamu orang yang fasik membawa suatu berita, maka selidikilah agar kamu tidak menimpakan suatu musibah kepada suatu kaum dengan tidak mengetahui, maka jadilah kamu menyesal atas perbuatanmu itu." (Al- Hujurat :6)

Kata tabayyun adalah bentuk masdar dari kata fatabayyanu yang artinya maka periksalah dengan teliti. Akar katanya adalah $b a^{\prime}-y a^{\prime}-n u n$ yang artinya berkisar pada jauhnya sesuatu yang terbuka. Sehingga kata tabayyun diartikan yaitu bahwa seseorang begitu saja menerima kabar dari orang lain yang patut dicurigai seperti orang fasik, dan hendaklah selalu mencari kejelasan dan 
ketetapan atas berita tersebut, terlebih lagi berita itu menyangkut hal yang penting ${ }^{31}$.

Sementara itu, kata tabayyun dalam bahasa arab memiliki beberapa arti; Pertama, Suatu usaha dalam mencari sesuatu yang dapat memperjelas dan menyingkap keadaan sesungguhnya. Kalimat tabayyana asy-syai berarti meneliti sesuatu hingga jelas. Kedua, kata tabayun diartikan sebagai upaya mempertegas sesuatu hakikat agat dapat memperjelas dan menyingkap keadaan sebenarnya. Kalimat tabayana al-qoumu al-amr berarti mereka telah merenungi dengan perlahan-lahan, tidak terburu buru sehingga permasalahan yang ada akan nampak jelas. Kalimat tabayana fi amrihi berarti seseorang memastikan dan meneliti suatu masalah dengan seksama ${ }^{32}$.

Quraish Shihab dalam tafsir al-Misbah menyebutkan bahwa surat alHujurat ayat 6 merupakan salah satu dasar yang ditetapkan agama dalam kehidupan sosial yang merupakan tuntunan yang sangat logis bagi penerimaan dan pengamalan suatu berita. Kehidupan manusia dan interaksi di dalamnya haruslah didasarkan pada hal-hal yang sudah diketahui dan dipahami kejelasannya. Manusia menyadari bahwa dirinya memiliki keterbatasan dalam menjangkau seluruh informasi yang ada, karena itu ia membutuhkan pihak lain yang jujur dan memiliki integritas sehingga dapat menyampaikan hal-hal yang benar, dan sebaliknya. Karena itu, informasi atau berita harus terlebih dahulu disaring, hal tersebut dimaksudkan agar jangan sampai seseorang melangkah tidak dengan data atau informasi yang jelas (ceroboh) sebagaimana disebut pada ayat kata jahalah yang berarti kebodohan. Disamping melakukannya berdasarkan pertimbangan logis dan nilai-nilai yang ditetapkan Allah swt, sebagai lawan dari makna jahalah ${ }^{33}$.

Realitas hari ini menunjukkan bahwa masyarakat muslim dalam berkomunikasi masih kurang memperhatikan tradisi tabayyun dalam kehidupan

\footnotetext{
${ }^{31}$ Depag RI. Al-Qur'an Dan Tafsirnya (Semarang: Effhar Offset, 2000), h. 402.

${ }^{32}$ Sayyid M. Nuh, Penyebab Gagalnya Dakwah Jilid I (Jakarta: Gema Insani 2005), h.

${ }^{33}$ Quraish Shihab, Tafsir Al Misbah (Jakarta: 2011), h. 589.
} 274. 
sosialnya. Pada umumnya orang begitu mudah percaya kepada berita di koran, majalah, radio, televisi dan sumber-sumber lainnya tanpa meneliti, mempelajari dan memikirkan hal tersebut. Sehingga yang terjadi adalah sering kita saksikan tindakan-tindakan dan sikap-sikap yang merugikan masyarakat secara umum. Banyak contoh yang mungkin telah kita saksikan dalam kehidupan keseharian kita, seperti informasi tentang teroris yang terus menerus mendiskriditkan Islam dan mengkait-kaitkannya dengan gerakan kelompok Islam fundamental. Sehingga masyarakat kita ada sebagian yang mencurigai kelompok pengajian-pengajian tertentu dengan mudahnya dituduh sebagai kelompok teroris.

\section{Penutup}

Komunikasi dalam kehidupan manusia sudah sangat dirasakan peran dan fungsinya begitu signifikan. Manusia sebagai makhluk yang sempurna diciptakan Allah ternyata tidak bisa hidup tanpa komunikasi, berkomunikasi yang dilakukan manusia menunjukkan disitulah letak kesempurnaan penciptaan manusia. Komunikasi yang dilakukan manusia dalam hidupnya adalah sebagai upaya untuk tetap menjaga dan memelihara eksistensi kehidupan pribadi dan kehidupan sosial serta mewujudkan kebaikan dan kebahagian hidup di dunia dan akhirat.

Sehingga apapun motif manusia berkomunikasi, hal itu menunjukkan bahwa komunikasi merupakan fitrah manusia. Sebagai sebuah fitrah maka komunikasi harus senantiasa dilakukan dengan penuh kesadaran dan penuh tanggung jawab. Hal itu dimaksudkan agar komunikasi yang dilakukan tidak membawa kerugian maupun bencana bagi manusia dan diri sendiri. Oleh karena itu, Islam sebagai agama rahmatan lil alamin memberikan beberapa pedoman atau etika melalui nilai-nilai yang terdapat di dalam Alquran dan Sunnah Nabi SAW tentang bagaimana sikap dan tingkah laku dalam berkomunikasi.

Komunikasi Islami mengajarkan kita menegakkan nilai-nilai kejujuran (kebenaran) dalam berkomunikasi, kemudian dalam berkomunikasi didasarkan pada perkataan yang baik (Falyakul Khairan au liyasmut), selain itu komunikasi islami juga menuntut seorang komunikator untuk teliti dan cermat dalam 
memahami sebuah informasi atau pesan yang diterimanya sebelum melanjutkannya kepada orang lain (nilai tabayyun). Ketiga nilai-nilai tersebut merupakan modal utama dan sebagai ukuran bagi setiap muslim dalam melakukan komunikasi, hal itu dimaksudkan agar proses komunikasi yang berlangsung mendatangkan suatu baikan dan keselamatan serta kebahagian bagi kehidupan umat manusia.

\section{Pustaka Acuan}

Saefullah, Ujang, Kapita Selekta Komunikasi: Pendekatan Agama dan Budaya, (Bandung, Simbiosa Rekatama Media, 2007).

Liliweri, Olo Komunikasi : Serba Ada Serba Makna, (Jakarta : Kencana, 2011).

Onong Uchana Effendy, Ilmu, Teori dan Filsafat Komunikasi, (Bandung: Citra Aditya Bakti, 2003).

Cangara, Hafied Komunikasi Politik; Konsep, Teori dan Strategi, (Jakarta : Raja Grafindo Persada, 2009).

Susanto, Eko Herry Komunikasi Politik dan Otonomi Daerah, (Jakarta : Mitra Wacana Media, 2009), h. 2.

Wiryanto, Pengantar Ilmu Komunikasi, (Jakarta: Grasindo, 2004).

Mulyana, Deddy, Ilmu Komunikasi Suatu Pengantar, (Bandung : Rosdakarya, 2007), h. 67.

Littlejohn, Theories Of Human Communication, (Belmont : Wadsworth Publishing Company, 1999).

Wiryanto, Pengantar Ilmu Komunikasi, (Jakarta: Grasindo, 2004)

Schramm, Wilbur The Process and Effect Of Mass Communication, (Urbajuna : University Of Lilinois Pres 1995).

Morissan, Teori Komunikasi : Individu Hingga Massa; Edisi Pertama, (Jakarta, Kencana Prenada Media Group, 2013).

Mulyana, Deddy, Ilmu Komunikasi Suatu Pengantar (Bandung : Remaja Rosdakarya, 2007).

Nata, Abudi, Al-Quran dan Hadits, (Jakarta : Raja Grafindo Persada, 1993).

Shihab, Quraish, Membumikan Al Quran (Bandung : Mizan, 2003). 
Tafsir Al Misbah (Jakarta: 2011).

Yuslem, Nawir, Ulumul Hadis (Jakarta : PT. Mutiara Sumber Widya, 2001).

Saefullah, Kapita Selekta Komunikasi : Pendekatan Budaya dan Agama, (Bandung : Simbiosa Rekatama Media, 2007), h. 67.

Mufid, Muhammad, Etika dan Filsafat Komunikasi (Jakarta: Kencana, 2010).

Sofyan, Ayi, Etika Politik Islam (Bandung: Pustaka Setia, 2012).

Latif, Mukhtar, Filsafat Ilmu (Jakarta: Kencana, 2014).

http: Seputarpengetahuan.com, 15 Pengertaian Etika Menurut Para Ahli (diakses pada tanggal 13 Desember 2015).

Kholil, Syukur, Komunikasi Islam (Bandung: Ciptapustaka Media, 2007).

Syafe'i, Al Hadis : Aqidah, Akhlak, Sosial dan Hukum), (Bandung : Pustaka Setia, 2000).

Saefullah, Kapita Selekta Komunikasi: Pendekatan Agama dan Budaya, (Bandung, Simbiosa Rekatama Media, 2007).

Rakhmat, Jalaluddin, Prinsip-prinsip Komunikasi menurut Al Quran : Makalah (http://sumut.kemenag.go.id/.

Munir, Metode Dakwah, (Jakarta : Kencana, 2006).

Depag RI. Al-Qur'an Dan Tafsirnya (Semarang: Effhar Offset, 2000).

M. Nuh, Sayyid, Penyebab Gagalnya Dakwah Jilid I (Jakarta: Gema Insani 2005).

Program Hadis Digital. 